\title{
COMPARISON COLLAGEN CONTENT OF THE SHELL OF A CLAM BLOOD(ANADARA GRANOSA) ANDSHELL OF CLAM GREENS(MYTILUS VIRIDIS) IN BANDENGAN, KENDAL, CENTRAL JAVA
}

\author{
Ariyanti Ariyanti ${ }^{1}$ Melani Dewi ${ }^{2}$ Alfenila Prasista Hapsari ${ }^{3}$ Syukron Mashadi ${ }^{4}$ \\ ${ }^{1}$ Program Studi Farmasi, STIKES Kendal \\ 2Program Studi Farmasi, STIKES Kenda \\ ${ }^{3}$ Program Studi Farmasi, STIKES Kendal \\ ${ }^{4}$ Program Studi Farmasi, STIKES Kendal \\ Corresponding author : riri99.cettaazzahra@gmail.com , alfenila@gmail.com
}

\begin{abstract}
Collagen is a major component of white connective tissue (white connective tissue) that covers nearly $30 \%$ of total protein in vertebrate organs and invertebrates. Collagen is a large molecular protein, a major component of the skin. More than $71 \%$ of skin protein is collagen. One source of collagen that can be used and not yet utilized is the shells of shells and shells of clam green. The use of collagen derived from animals that live in the air can be a promising alternative, given the usual commercial collagen of cowhide, pig skin, or chicken skin. The population in this study is the shell of blood clams (Anadaragranosa) and the shells of clam green (Mytilusvaridis) taken from the fish auction site in Bandengan, Kendal. Samples will be treated differently to the concentration of acetic acid dancer fluid and the extraction time which will affect the yield of collagen produced.The research design used was pre experiment. Only one case design/case study is treated/ intervened.

The study was analyzed comparatively ie the effectiveness of acetic acid and the immersion time in yield of collagen yield from the shells and shells of clam greens. Data is processed and analyzed using spss with t-test.There is no difference in average levels of collagen shells of clams of blood and shells of green shells. The acetic acid treatment of $0,75 \mathrm{M}$ resulted in the highest yield of 2,03\% for the shells of clams and $1,96 \%$ for the shells of green shells. Treatment of 2 days extraction time yields the highest yield of $1,74 \%$ for the shells of clam and $1,85 \%$ for the shells of green shells.
\end{abstract}

\section{Keywords : Anadara granosa, Mytilus varidis, collagen}

\section{Introduction}

Indonesia is one of the largest archipelagic countries in the world, where two-thirds of Indonesia's territory consists of the sea. As one of the Indonesian archipelago, Central Java Province has a total of $656.1 \mathrm{~km} 2(0,81 \%$ of the total length of Indonesian coastline) divided into the northern and southern regions. Fisheries in the northern region of Central Java is supported by several areas of Kendal one city that has abundant fish resources and much interest to the community Kendal. Besides fish, another potential of coastal waters in Kendal is shellfish. Types of shellfish are often the community's consumption of green shells (Mytilus viridis),

Volume 1 Issue 1 (2018) blood clams (Anadara granosa) and fur shells (Anadara antiquata). The shells used as the object of this study were blood clams. The area of this shell spreads almost across the Indonesian coast, living at the base, in a muddy sand area at depths of up to 4 meters and relatively calm waters (Hapsari, 2017).

From the potential of shellfish, most people only use shell meat while the shellfish is not utilized optimally, only $20 \%$ of shellfish waste is produced as feed, handicrafts and other products (Anwar, et al., 2011). The shells of blood clams are one of the alternative sources in the production of untapped collagen. According 
Table 1. The Chemical Content of Mussel Shells Component Composition (\%)

\begin{tabular}{cl}
\hline $\mathrm{Ca}+\mathrm{C}$ & 98,77 \\
$\mathrm{Mg}$ & 0,0476 \\
$\mathrm{Na}$ & 0,9192 \\
$\mathrm{P}$ & 0,0183 \\
$\mathrm{~K}$ & 0,0398 \\
etc. & 0,1981
\end{tabular}

Utilizing collagen derived from animals that live in water can be a promising alternative, given that commercial collagen is usually obtained from cowhide, pig skin, or chicken skin (Setyowati and Setyani, 2015). Collagen is the main structural component of white connective tissue, which accounts for nearly $30 \%$ of total protein in vertebrate or invertebrate organs (Setiawati, 2009). Collagen on the market is used as raw material in the food industry, cosmetics, filmmaking, biomaterials and pharmaceuticals. In the pharmaceutical industry collagen is used as a drug carrier that is mini-pellets and tablets for protein carrier, gel formulations in combination with liposomes for controlled delivery systems, controlling agents for transdermal delivery and nanoparticles for gene delivery (Nurhayati et al., 2013).

Collagen can be obtained through the extraction of collagen source materials using

\section{Method}

\section{Materials and tools}

The main research raw material is the shell of blood shells and the shells of green shells taken from the fish auction place in Bandengan area, Kendal city. The chemicals used are $\mathrm{NaOH}$, $\mathrm{NaCl}, \mathrm{CH} 3 \mathrm{COOH}$, aquades.

The equipment used in this research are beaker glass, oven, stirring rod, glass funnel, measuring cup, filter paper, centrifuge, analytical scales,

\section{Sample Setup}

Shellfish is cleaned and powdered. The sample was then weighed at a ratio of 1:20 (w/ v) and then immersed in a $0,1 \mathrm{M} \mathrm{NaOH}$ solution for 24 hours. The sample was filtered using filter paper, then washed with aquadest until the sample $\mathrm{pH}$ approached or reached $\mathrm{pH} 7$. organic acids or inorganic acids. An importantfactor affecting the end result of collagen is the concentration and immersion time in acetic acid solution. The concentration of acetic acid can change the $\mathrm{pH}$ that regulates protein charge density that modifies the electrostatic interactions and protein structure. The extraction process is also affected by time because time is critical to the molecular transfer of substances during the diffusion process (Djailani, 2016). According to Minah et al., (2016), the immersion stage must be done appropriately (time and concentration), so as not to happen the collagen solubility in solution and cause the decrease of yield. Therefore, to optimize the use of solid waste shells as collagen will be conducted research on the effect of concentration of acetic acid and soaking time on the collagen content of the shells of blood shells produced.

\section{Collagen Extraction Process}

Collagen extraction was performed by immersion in acetic acid in reference to modified Muyonga et al. (2004). The shells of the blood and the shells of the green shells were weighed by the ratio of sample weights and the volume of 1:10 (w/v) solution, then treated with treatment $\mathrm{A}$ and treatment $\mathrm{B}$. Treatment $\mathrm{A}$ was macerated in 0,25 acetic acid; 0,5 and $0,75 \mathrm{M}$ with a 3 -day extraction time. Treatment B was macerated in $0,75 \mathrm{M}$ acetic acid with an extraction time of 1 , 2and 3 days. The result of treatment extraction $\mathrm{A}$ and treatment $\mathrm{B}$ was then salted out by adding $\mathrm{NaCl}$ 0,9 M. Then centrifuged for 10 minutes at $10,000 \mathrm{rpm}$ to precipitate wet collagen residue fibers. The separation results were then filtered and stirred at $60^{\circ} \mathrm{C}$. for one day to obtain dry collagen. Dry collagen is then weighed to calculate the amount of rendemen obtained. 
Rendemen $(\%)=\frac{\text { Berat kolagen kering }}{\text { Bobot awal serbuk }} \times 100 \%$

\section{Results And Discussion}

Collagen extraction from the shells of blood clams (Anadaragranosa) and the shells of green shells (Mytilusvaridis) using the maceration method. The maceration method is one of the cold extraction methods. The use of this method is quite effective because the contact between the simplisia and the solvent takes a long time, besides collagen itself can not stand the heat then with this method of collagen will be more perfectly seared.

In the early stages, the shell of blood clams passes through the washing process and then is powdered to expand the surface. The powder is then soaked with $0,1 \mathrm{M} \mathrm{NaOH}$ for 24 hours which aims to remove the non-collagen component characterized by a cloudy white soaking solution, since the non-collagen component exits and unites with the solvent. Immersion with $\mathrm{NaOH}$ resulted in the collagen structure expanding due to water penetration. This results in non-collagen components originally trapped within the collagen matrix can easily be released. The sample of $\mathrm{NaOH}$ treatment was divided into 2 treatments.

Treatment A was immersed in acetic acid with a concentration variation of $0,25 \mathrm{M} ; 0,5 \mathrm{M}$ and $0,75 \mathrm{M}$ for 3 days. Treatment $\mathrm{B}$ was immersed in $0,75 \mathrm{M}$ acetic acid concentration with variation of immersion time of 1 day, 2 days and 3 days. The extraction process uses an acid solvent instead of a base because the acid is able to convert the triple helical collagen fibers into a single chain, whereas the basic immersion solution is only capable of producing double chains. This causes the collagen to be hydrolyzed by the acid solution more than the basic solution. The alkaline solution takes a longer time to hydrolyze the collagen (Kasim, 2013). Acetic acid is widely selected as a solvent in collagen extraction because it can extract better than other solvents (Astiana et al., 2016). Kasim (2013) states that the amount of collagen extracted using acetic acid is higher than using citric acid and hydrochloric acid.

Acetic acid capable of dissolving collagen that does not crosslink. According to Astina et al., (2016), immersion in acidwill cause skin development due to ingress of water in collagen fibers. The entry of water into the collagen fibers is due to the electrostatic forces between the polar groups in the collagen fibers with $\mathrm{H}+$ from the aatue forming the hydrogen bond between the non-polar group on the collagen fiber with $\mathrm{H}+$ from the acid. Development of this skin will damage the structure of collagen fibers due to disruption of non-covalent bonds that will dissolve the collagen in acetic acid solution.

The screening results of each treatment were then precipitated or precipitated by collagen salting out using a $0,9 \mathrm{M} \mathrm{NaCl}$ solution. The addition of a salt of high concentration would cause salting out where the salt binds water and cause aggregation of the proteins so that the protein molecule undergoes precipitation. The result is due to the ionic strength of salt higher than the protein so it is easy to bind water. The amount of water attached to the protein decreases causing an attractive force between the protein and water molecules resulting in protein precipitation (Astina, et al., 2016).

Table 2. Percentage Rendemen Treatment A On Immersion 3 Days

\begin{tabular}{ccc}
\hline \multirow{2}{*}{$\begin{array}{c}\text { Concentration } \\
\text { levels(M) }\end{array}$} & \multicolumn{2}{c}{ Levels of collagen rendement(\%) } \\
\cline { 2 - 3 } As. asetat 0,25 & Cangkang kerang darah & Cangkang kerang hijau \\
\cline { 2 - 3 } & 0,55 & 0,71 \\
\cline { 2 - 3 } & 0,97 & 1,04 \\
\cline { 2 - 3 } As. asetat 0,5 & 0,22 & 1,12 \\
\cline { 2 - 3 } & 0,94 & 1,34 \\
\hline \multirow{2}{*}{ As. asetat 0,75} & 1,03 & 1,51 \\
\cline { 2 - 3 } & 1,08 & 1,85 \\
\cline { 2 - 3 } & 1,61 & 1,68 \\
\hline
\end{tabular}


The precipitate results are centrifuged for $10 \mathrm{~min}$ at a rate of $30,000 \mathrm{rpm}$ to precipitate wet collagen residue fibers. The separation results were then filtered and stirred at $60^{\circ} \mathrm{C}$. for one day to obtain dry collagen. Dry collagen is then weighed to calculate the amount of rendemen obtained. Higher concentrations of acetic acid solution can cause a decrease in protein levels because acetic acid will hydrolyze stronger peptide bonds resulting in protein loss (Tridhar, 2016). According Ulfah (2011), the highest yield of collagen is produced by chicken claws soaked in acetic acid solution, where the higher concentration of acetic acid the collagen structure will be more open.

According to Naro (2013), the extraction of black tilapia fish samples using $0,75 \mathrm{M}$ acetic acid concentration resulted in a larger percentage of collagen rendement $(5,96 \%)$. This shows that the concentration factor of acetic acid solution has an effect on collagen protein extraction.

Table 3. Results Calculation Indepedent Samples Test Rendemen Treatment A

\begin{tabular}{|c|c|c|c|c|c|}
\hline \multirow{3}{*}{$\begin{array}{l}\text { Levels of } \\
\text { collagen } \\
\text { rendement }\end{array}$} & & \multicolumn{2}{|c|}{$\begin{array}{c}\text { Levene's Test for } \\
\text { Equality of } \\
\text { Variances }\end{array}$} & \multicolumn{2}{|c|}{$\begin{array}{c}\text { t-test for Equality of } \\
\text { Means }\end{array}$} \\
\hline & & F & sig & $\mathrm{t}$ & Sig \\
\hline & $\begin{array}{c}\text { Equal variances } \\
\text { assumed }\end{array}$ & 0,239 & 0,631 & $-1,455$ & 0,165 \\
\hline & $\begin{array}{c}\text { Equal variances } \\
\text { not assumed }\end{array}$ & & & $-1,455$ & 0,166 \\
\hline
\end{tabular}

Based on the calculation results of independent test samples in table 3, the significant value of $\mathrm{T}$ test showed the number 0,166 or $\mathrm{p}>0,05$; then $\mathrm{H} 0$ and $\mathrm{H} 1$ rejected or it

could be concluded that both the average yield levels of collagen in blood and shell mussel shells mussels are thesame.

Table 4. Percentage of Reaction in Treatment of B in Acetic Acid Immersion 0.75 M

\begin{tabular}{|c|c|c|}
\hline \multirow[b]{2}{*}{ Extraction time } & \multicolumn{2}{|c|}{ Collagen Reagent Level (\%) } \\
\hline & Blood clam shells & Green clam shell \\
\hline \multirow{3}{*}{$\begin{array}{l}1 \text { day Extraction } \\
\text { time }\end{array}$} & 1,07 & 0,71 \\
\hline & 1,06 & 1,12 \\
\hline & 1,12 & 1,04 \\
\hline \multirow{3}{*}{$\begin{array}{l}2 \text { day Extraction } \\
\text { time }\end{array}$} & 1,08 & 1,34 \\
\hline & 1,74 & 1,85 \\
\hline & 1,14 & 1,51 \\
\hline \multirow{3}{*}{3 day Extraction } & 1,00 & 1,68 \\
\hline & 0,91 & 1,96 \\
\hline & 0,98 & 1,71 \\
\hline
\end{tabular}

From table 4, it can be seen that the process of extracting blood samples of shells from the first day to the second day experienced a temporary rise on the third day decline. According Minah et al., (2016), the hydrolysis of collagen by soaking in an acid solution requires a shorter time than by soaking in an alkaline solution because the acid is able to change the triple helix collagen fibers into a single chain. Stages of immersion must be done properly (time and concentration), in order to avoid the solubility of collagen in solution and cause a decrease in yield generated. 
Table 5. Results of Calculation of Independent Samples Test for Treatment of B

\begin{tabular}{|c|c|c|c|c|c|}
\hline & & $\begin{array}{r}\text { Levene } \\
\text { Equ } \\
\text { Vari }\end{array}$ & $\begin{array}{l}\text { st for } \\
\text { of } \\
s\end{array}$ & $\begin{array}{c}\text { t-test for Equality } \\
\text { of Means }\end{array}$ & \\
\hline & & $\mathrm{F}$ & sig & $\mathrm{t}$ & sig \\
\hline Collagen & $\begin{array}{c}\text { Equal variances } \\
\text { assumed }\end{array}$ & 4,562 & 0,048 & $-1,955$ & 0,068 \\
\hline yield & $\begin{array}{c}\text { Equal variances not } \\
\text { assumed }\end{array}$ & & & $-1,955$ & 0,073 \\
\hline
\end{tabular}

Based on the calculation of indipedent sample testin table 5 , significant values indicate the numbers of 0,068 or $\mathrm{p}>0,05$; then $\mathrm{H} 0$ is accepted and $\mathrm{H} 1$ is rejected or it can be concluded that both the average chitosan content rate between the shellfish shell waste and the milkfish burrl waste are the same.

\section{Conclusions}

1. There is no difference in average levels of collagen shells of clams of blood and shells of green shells

2. The acetic acid treatment of $0,75 \mathrm{M}$ resulted in the highest yield of 2,03\% for the shells of clams and 1,96\% for the shells of green shells.

3. Treatment of 2 days extraction time yields the highest yield of 1,74\% for the shells of clam and $1,85 \%$ for the shells of green shells

\section{Reference}

Anwar, K., Rinaldi, R., Nisa, H., Sitepu, S.F., 2011, Pasta Gigi Cakradent, Pasta Gigi Cangkang Kerang Sehat Tanpa Flouride dan SLS, Proposal Program Kreativitas Mahasiswa Universitas Negeri Medan, Medan.

Astiana, I., Nurjanah., Tati N., Karakteristik Kolagen Larut Asam Dari Kulit Ikan Ekor Kuning, Jurnal IPB, Fakultas Perikanan dan Ilmu Kelautan IPB, Bogor.

Hapsari, Alfenila P., 2017, Pengaruh Konsentrasi Asam Asetat dan Waktu Volume 1 Issue 1 (2018)

\section{Ekstraksi terhadap Kadar KolagenCangkang Kerang Darah(Anadara Granosa) di Daerah Bandengan, Karya Tulis Ilmiah, Program Studi D-III Farmasi STIKES Kendal, Kendal}

Kasim, S., 2013, Pengaruh variasi Jenis Pelarut Asam Pada Ekstraksi Kolagen Dari Ikan Pari (Himantura gerrardi) dan Ikan Tuna (Thunnus sp),Majalah Farmasi dan Farmakologi, Fakultas Farmasi Universitas Hasanuddin, Makassar.

Marjoni, Mhd. Riza, 2006, Dasar-Dasar Fitokimia Untuk Diploma III Farmasi, Cetakan I, 20, Trans Info Media, Jakarta.

Minah, Faidliyah N., Siga, Wea Drira M., S., Catur Pratiwi, 2016, Ekstraksi Gelatindari Hidrolisa Kolagen Limbah Tulang Ikan Tuna dengan Variasi Jenis Asam dan Waktu Ekstraksi, Seminar Nasional Inovasi dan Aplikasi Teknologi di Industri, Institut Teknologi Nasional Malang, Malang.

Naro, AB., 2013, Ekstraksi dan Karakterisasi Kolagen dari Kulit Ikan Nila Hitam (Oreochoromis niloticus),Skipsi, Fakultas pertanian Universitas Gadjah Mada, Yogyakarta.

Nasution, Jeffry Haryadi, 2015, Pembuatan Adsorben Dari Cangkang Kerang Bulu Yang Daktivasi Secara Termal Sebagai 
Pengadsorbsi Fenol, Skripsi, Fakultas Teknik Universitas Sumatera Utara, Sumatera.

Nurhayati, Tazwir, Murniyati, 2013, Ekstraksi dan Karakterisasi Kolagen Larut Asam Dari Kulit Ikan Nila (Oreochromis niloticus).JPB kelautan dan Perikanan, Balai Besar Penelitian dan Pengembangan Pengolahan Produk dan Bioteknologi Kelautan dan Perikanan, Jakarta.

Nurjanah, Zulhamsyah, Kustiyariyah., 2005, Kandungan Mineral dan Proksimat Kerang Darah (Anadara granosa) Yang Diambil Dari Kabupaten Boalemo, Gorontalo. Buletin Teknologi Hasil Perikanan, Fakultas Perikanan dan Ilmu Kelautan Institut Pertanian Bogor, Bogor.

Setiawati, I. H., 2009, Karakterisasi Mutu Fisika Kimia Gelatin Kulit Ikan Kakap Merah (Lutjanus Sp.) Hasil Proses
Perlakuan Asam, Skripsi, Fakultas Perikanan dan Ilmu Kelautan Institut Pertanian Bogor, Bogor.

Setyowati, H., dan Wahyuning S., 2015, Potensi Nanokolagen Limbah Sisik Ikan Sebagai Cosmeceutical, Jurnal Farmasi Sains dan Komunitas, Fakultas Farmasi Universitas Sanata Dharma, Yogyakarta.

Tridhar, Noorman A., 2016, Perbandingan Produksi Kolagen dari Sisik dan Tulang Ikan Gurami (Osphronemus gouramy) Secara Kimia dan Enzimatis, Skripsi, Fakultas Teknik Universitas Pasundan, Bandung.

Ulfah, M., 2011, Pengaruh Konsentrasi Larutan Asam Asetat dan Lama Waktu Perendaman terhadap Sifat-Sifat Gelatin Ceker Ayam, AGRITECH, Fakultas Teknologi Pertanian, Yogyakarta. 